Faculty of Philosophy, University of Niš, Serbia

DOI: https://doi.org/10.46630/msae.1.2020.04

\title{
SEARCHING FOR PUBLIC INTEREST ON THE INTERNET ${ }^{3}$
}

\begin{abstract}
The new information and communication environment on the Internet is governed by private agents called Internet intermediaries. Although we could already deduce their position as mediators in communication on the Internet from the very name and the fact that their platforms are valuably neutral and technically driven by algorithms, we cannot disregard their role in disseminating information and its influence on users, which often goes beyond technical mediation itself. The purpose of the research is to point out that social networks and search engines, as Internet intermediaries, are not only techno giants but also that, in some respects, perform media-like functions, and should be approached in accordance with that role. Being the private companies, these new agents should, in addition to commercial ones, fulfill the demands of users, who are not mere consumers of their services, but also citizens. From their citizen position, the users can demand the fulfilment of the public interest, which may not or should not necessarily be identical to the traditional understanding of that particular concept, but rather conditioned by the context and environment in which a particular demand is made.
\end{abstract}

Key words: Internet, intermediaries, public interest, search engines, social networks

\section{Introduction}

In the case of the public interest, we encounter at least two challenges; the first concerning this fluid concept conditioned by many variables and the second, more crucial challenge, which has gained importance in recent years and raised the question in what spheres of communication and information the demand for the public interest can be applied. The latter challenge became more complex by the dominance of online communication and massive use of private companies' services on the Internet. Those companies are no longer regarded as neutral platforms free of responsibility for the distributed content, but rather as new agents providing mass dissemination of information, bringing certain functions closer to the media (Jakubowich, 2009). In such a relationship, can users justifiably expect private companies on the Internet, among which we primarily include social networks and search engines, to work in their favor and assume responsibility for communication processes they

\footnotetext{
${ }^{1}$ Received August 2019 / Accepted November 2019

${ }^{2}$ E-mail: marta.mitrovic@filfak.ni.ac.rs

${ }^{3}$ Prepared as a part of the project Sustainability of the Identity of Serbs and National Minorities in the Border Municipalities of Eastern and Southeastern Serbia (179013), conducted at the University of Niš Faculty of Mechanical Engineering, and supported by the Ministry of Education and Science of the Republic of Serbia.
} 
moderate, parallel to powerful positions they won in the information and communication ecosystem? In other words, can we request the public interest online? In order to require new communication and information agents to work in the public interest, we must primarily show that their role in creating public opinion is so important that it can cause changes in social and political reality.

The most recent examples that speak in support of this thesis are based on the suspicion that Facebook had a decisive role in the victory of the US president Donald Trump, precisely the fabrication of fake news, as well as the fact that the final outcome of the UK referendum (Brexit) was influenced by information on social media (Allcott \& Gentzkow, 2017; Rainie, Anderson \& Albright, 2017). Even before these examples from Western countries, the revolutions in the Arab countries were called "Twitter revolutions" because of what was believed to be the crucial influence of Twitter as the driving force for protesters and generators of citizen dissatisfaction, on the one hand, and tweets as a compensation for the inadequate reporting of traditional media, on the other (Lotan et al., 2011). It should be emphasized that the role of social media in those events is probably overstated, in some respects, quite far from the truth (Radok, 2015), but that does not mean that these platforms do not have or shall not have power to change governmental authority and shape the world order in the future. This assumption is an adequate reason to approach the analysis of influence and power of private companies in a more serious way, and to speak more often of their responsiblity to the public interest. The purpose of this research paper is to demystify information and communication agents on the Internet as neutral platforms and, in accordance with their roles and power in the communication and information ecosystem, position them in relation to the public interest.

In compliance with the purpose, the following research questions are:

1. What is the influence and importance of search engines and social networks on informing users and the formation of socio-political opinion?

2. Are search engines and social networks, as private agents, obliged to fulfill the demand for the public interest, and in what way can they achieve this?

We will try to provide the answer to the first research question through a critical analysis of the roles and importance of private information and communication agents on the Internet. Also, we will offer the interpretation of a secondary research in this area in order to arrive at a more accurate conclusion. In order to answer the second research question, first we will analyze the concept of the public interest through the prism of the online sphere and then combine the findings with the answer to the first research question and attempt to determine, in accordance with the already established role of private agents, the need and possibility of fulfilling the demand for the public interest on the Internet.

\section{Who is shaping the information and communication landscape on the Internet?}

Even though it was originally created for military purposes, the Internet has quickly transformed into a space dominated by private companies. Almost every 
activity on the web is enabled by a private company. For our research, the most relevant are private companies that represent the information bloodstream - search engines and social networks. These companies belong to the class of Internet intermediaries among which we include agents that mediate the online communication between two or more parties. They can host the content, distribute it, enable access, etc. In addition, there are different types of Internet intermediaries: for access (Internet service providers), for payment (PayPal), for purchase and sale (Amazon), for navigation (search engines - Google), for participation (social networks - Facebook) (Perest, 2010: 9).

Our focus is on search engines and social networks, since they are the intermediaries in a direct relationship with users, providing content variety: from political to entertainment, at the same time giving them the opportunity to participate and create their own content. Because of the services they provide, we consider that they can potentially influence the creation of public opinion. Therefore, in the continuation of this research paper, when we mention Internet intermediaries, we will refer to these two types. There have been numerous discussions regarding the implications the aforementioned Internet intermediaries have in informing the (global) public. In most cases, their responsibility is being discussed, because it is indubitably clear that in developed countries these agents represent the greatest disseminators of information. However, should they be regarded as neutral technocompanies, platforms that do not produce and offer their own content, but only serve to distribute information? If we agree that the intermediaries, who are the subject of the research, are only neutral platforms, it would also mean they are completely released of any liability for the content spreading through their info-routes. However, in the last few years, we have witnessed the situation where the European communication policy does not free the intermediaries of responsibility.

On the contrary, there is an increasing number of acts treating these agents as the ones responsible for the issues of freedom of expression (Declaration on freedom of communication on the Internet ${ }^{4}$ ), privacy and protection of personal data (General Data Protection Regulation - GDPR ${ }^{5}$ ), hate speech (The EU code of conduct on countering illegal hate speech online ${ }^{6}$ ), copyright (EU Directive 2019 on copyright and related rights in the Digital Single Market ${ }^{7}$ ). It is evident that European countries do not consider that only self-regulatory mechanisms of these private companies can guarantee the respect of user rights, but also the national laws of the countries in

\footnotetext{
${ }^{4}$ Declaration on freedom of communication on the Internet (Adopted by the Committee of Ministers, Council of Europe) https://www.osce.org/fom/31507?download=true (accessed August 3, 2019).

${ }^{5}$ https://gdpr-info.eu/ (accessed August 3, 2019).

${ }^{6} \mathrm{EU}$ Code of conduct on countering illegal hate speech online https://ec.europa.eu/info/policies/justiceand-fundamental-rights/combatting-discrimination/racism-and-xenophobia/countering-illegal-hatespeech-online_en

${ }^{7}$ Directive (EU) 2019/790 of the European Parliament and of the Council of 17 April 2019 on copyright and related rights in the Digital Single Market https:/eur-lex.europa.eu/eli/dir/2019/790/oj (accessed August 3, 2019).
} 
which they operate. The tendency for stronger regulations in this area is becoming more intense. At this point, we could go back to the beginning, to a time when the Internet was in the early stages of development and remember that before its commercialization, the "natives" of the Internet space believed in the Internet free from the grip of the state (Goldsmith \& Wu, 2006). The visions of the "founding fathers" implied that the Internet was a physically separated space from the real; a virtual space with no place for state repression, by which they also meant minimal regulatory interventions ${ }^{8}$. Strongly believing in the self-regulating ability of the Internet, Internet libertarians - adherents of the Internet as an absolutely free space - insisted that the Internet community, formed beyond the physical world and its rules, was capable of shaping a kind of "an online parallel universe" with its own rules and functioning system. However, the period of believing in the Internet free and independent of governments and laws, did not last long (Palfrey, 2010 ${ }^{9}$ ).

On the one hand, the commercialization of the Internet, which involves the flourishing of private companies that are shaping the online sphere nowadays, and the evident power that Internet communication and informing showed in socio-political relations, on the other, have led to a growing involvement of countries in the Internet space. Although the intensity of participation tends to vary, it is conditioned by the political and cultural attitude towards regulation in general. For example, in the United States of America the model of self-regulation is still dominant, with noticeably greater involvement of the government, while in Europe there is a traditionally stronger regulation, with a tendency of increasing intensity. Therefore, the main agents in the Internet-mediated communication and those shaping the Internet landscape, on the one hand, are private companies that provide their services online, but on the other hand, supernational entities (such as the European Union), whose role is to regulate and co-regulate the Internet space, as well as the users of Internet services with their own demands and expectations. Each of these parties has their own demands and interests: the intermediaries are primarily focused on the commercialization and profitable business; the national interest is the most important aspect to countries, that is, the preservation of the contested jurisdiction in the age of the Internet; while users are primarily interested in the quality of services and the realization of their interests, which we may call user or, in the wider context, the public interest.

\footnotetext{
${ }^{8}$ In A Declaration of the Independence of Cyberspace, published in 1996, John Perry Barlow indicated that: "Governments of the Industrial World, you weary giants of flesh and steel, I come from Cyberspace, the new home of Mind. On behalf of the future, I ask you of the past to leave us alone. You are not welcome among us. You have no sovereignty where we gather. [...] Our identities have no bodies, so, unlike you, we cannot obtain order by physical coercion. We believe that from ethics, enlightened selfinterest, and the commonweal, our governance will emerge. [...] We will spread ourselves across the Planet so that no one can arrest our thoughts. We will create a civilization of the Mind in Cyberspace. May it be more humane and fair than the world your governments have made before" (full text available at : https://www.eff.org/cyberspace-independence), (accessed August 3, 2019).

${ }^{9}$ Palfrey (2010) offers a chronological account of the development of the Internet and divides it into four phases: Open internet (from the 1960 until 2000), Access denied (2000-2005), Access controlled (20052010), Access contested (2010 - through the present day). With a transition into a new phase, the Internet becomes more controlled.
} 


\section{Intermediaries - media-like agents}

In order to answer the first research question: What is the influence and importance of search engines and social networks on informing users and the formation of socio-political opinion?, we must first determine their position in a complex information and communication system. Napoli writes about the developing media ecosystem: "in which algorithmically driven platforms such as social media and search engines are playing an increasingly significant role in the production, dissemination, and consumption of the news and information that are essential to a wellfunctioning democracy" (Napoli, 2014 ${ }^{10}$ ). If we agree with the cited author, we can question the responsibilty of so many significant agents. Namely, in recent past, traditional media were the primary sources, disseminators of information and the creators of public opinion. For example, different types of regulations were imposed on electronic media, because of their indisputable influence on the formation of public relations towards socio-political environment. If those roles are taken over by search engines nowadays, by social networks particularly, does that mean we can expect from them the same kind of responsibility? Ultimately, are they to be considered the media?

Karol Jakubowicz tried to answer that question in 2009, at the first Conference of Ministers responsible for the Media and New Communication Services in Reykjavik, in a text $A$ New Notion of Media?. Starting from the functions that were recently attributed exclusively to the media in the traditional sense of that concept, Jakubowicz analyzed the functions of new agents operating on the Internet and compared them to the functions of the media. The author emphasized the six criteria, which serve to determine whether a certain entity can be recognized as belonging to the media: 1) purpose - to inform, educate, entertain, maximize the audience, be a debate space, etc. 2) editorial policy - the existence of gatekeepers 3) employees as journalists and other content creators 4) the existence of period dissemination 5) public nature - to make information public 6) conformity with normative, ethical and professional standards operating in accordance with the suggested standards (Jakubowicz, 2009: 9).

Furthermore, Jakubowicz divided the criteria into hard and soft, stating that: "while 'hard, formal criteria (technology for content dissemination, periodic dissemination, full-time journalists, etc.) are important, what really determines whether we have to do with a media organisation and media or media-like content is 'soff' criteria" (2009: 10 ), by which the author implies purpose, editorial policy and normative standards. Applying the 'soft' criteria onto the business of new agents or Internet intermediaries, Jakubowicz stated that the purpose has remained more or less the same, that the existence of editorial policy is limited but occurrs in new forms in the business of these agents ${ }^{11}$,

\footnotetext{
${ }^{10}$ Napoli, P. (2014). Digital intermediaries and the public interest standard in algorithm governance. Media Policy Blog. http://eprints.lse.ac.uk/80242/ (accessed August 2, 2019).

${ }^{11}$ Jakubowicz gave an example of Google News, a generated news platform that is personalized, with algorithmically arranged content, so that it follows a personalized user experience, whereby the algorithm is guided by traditional news features, such as relevance, proximity, topicality, etc. For that reason, the author considers that editorial policy is present in new platforms as well, but in accordance with technical characteristics, has been changed in relation to the traditional understanding (Jakubowicz, 2009: 17).
} 
while respecting ethical standards and norms has been equally important, regardless of the medium responsible for disseminating information. Also, by analyzing the roles of new gatekeepers, Jakubowicz believes that they exist in new platforms, but their nature is slightly changed and often algorithmically programmed and adds: "Where elements of a gate-keeping role persist in new communication services, this might indicate that we have to do with media or media-like activities" (2009: 17). Based on the aforementioned reasons, the author considers that new agents cannot be perceived as the media in the traditional sense, because they do not produce content or employ journalists. However, they are certainly the greatest disseminators of information, those who edit content, either algorithmically or traditionally ${ }^{12}$, so we have to regard them as the media-like agents, whose content is referred to as the media-like content.

If Internet intermediaries, led by search engines and social networks, have come closer to traditional media, that also means their responsibility to users should be proportional to their role. Nevertheless, companies such as Google or Facebook refuse to be defined as the media, calling themselves technological, while with the concept of "platform" they tend to suggest the role of a neutral information carrier (Gillespie, 2010). Their insistence on technological terminology and refusal to be compared to the media suggests that any relationship with the media in the traditional sense would only intensify the discussion about their responsibility: "If Twitter, Facebook, and Google were media companies, they would be held $100 \%$ accountable for the content that appears on their platforms" (Serwer \& Zahn, 2019). However, due to the role that search engines and social networks have in informing and in users' political decisions, the professional public is more openly and intensively bringing their business into connection with the bussiness of media companies. In that context, Steve Kovach (2017) states that: "Facebook and the rest of Big Tech are now Big Media, and it's time we start treating them that way" adding that "Facebook's news feed has become what the front page of the newspaper was for older generations of people; at least $66 \%$ of the social network's 2 billion users rely on it as a news source $[. .$.$] Meanwhile, consumers turn to Twitter for breaking news, and they$ search Google for news updates". ${ }^{13}$ According to the research conducted by the Pew Research Center, six out of ten Americans get news on social networks: "Two-thirds of Facebook users (66\%) get news on the site, nearly six-in-ten Twitter users (59\%) get news on Twitter, and seven-in-ten Reddit users get news on that platform. On Tumblr, the figure sits at 31\%" (Shearer, Gottfried, 2016) ${ }^{14}$. According to a research conducted in 2018: "A median of $42 \%$ among the 38 countries surveyed say they get

\footnotetext{
${ }^{12}$ In addition to their algorithmic content editing in recent years, Internet intermediaries have been employing a growing number of content moderators, who control a potentially harmful content. See:"Facebook news selection is in hands of editors not algorithms, documents show". The Guardian. https://www.theguardian.com/technology/2016/may/12/facebook-trending-news-leaked-documentseditor-guidelines (accessed August 4, 2019).

${ }^{13}$ See: https://www.businessinsider.com/facebook-and-google-are-now-media-companies-2017-10 (accessed August 5, 2019).

${ }^{14}$ The entire research is available at: https://www.journalism.org/2016/05/26/news-use-across-socialmedia-platforms-2016/ (accessed August 6, 2019).
} 
news on the Internet at least once a day. In 14 countries, half or more adults get news online daily".

As for social networks, "The median percentages of people who get news at least once a day through social media are about the same in emerging and developing economies as in advanced ones (33\% and 36\%, respectively).

Overall, a global median of 35\% get news daily through social media, with the highest levels in South Korea (57\%), Lebanon (52\%) and Argentina (51\%)" (Mitchell et., al, 2018) ${ }^{15}$.

From the presented research, it can be concluded that the Internet, led by social networks, is becoming one of the main sources of information for people around the world. Most often, people get news on the social networks that have the predetermined algorithms able to offer personalized information (editorial-like role) (Musiani, 2013) or by a direct search, where search engines determine which information will be offered first based on the algorithmic calculations, in relation to a searched term (editoriallike role) (Grimmelmann, 2017). The ability of private companies, such as Google or Facebook, to edit our communication and information space on the Internet by their algorithms, imposes the answer to the first research question: the role of search engines and social networks in informing and political decision-making of users is significant that we can only assume its intensity in the future; the influence that these intermediaries achieve in the new communication and information space will be the subject of some future research, while the affairs concerning the fabrication of fake news, their influence on political elections and referendums give us a reason to perceive their already immense influence, without properly assessing its value.

\section{Public Interest vs Commercial Interest}

In order to answer the second research question Are search engines and social networks, as private agents, obliged to fulfill the demand for the public interest, and in what way can they achieve this?, we must precisely determine the definition of the public interest in the traditional information environment and then apply that concept to a new one. Public interest is a fluid concept that cannot be determined beyond the context and conditions in which the demands for its fulfillment are initiated (McQuail, 1994). For example, in different governances or in different time periods, the fulfillment of the public interest demand can be observed in numerous ways. The most frequent demands related to the public interest are freedom of expression/ information, providing information from various sources, political, economic or any other independence in the media work, etc. ${ }^{16}$. Also, these demands are achieved through two mechanisms at least, regulation and/or self-regulation.

\footnotetext{
${ }^{15}$ The research conducted by the Pew Research Center is available at: https://www.pewresearch.org/ global/2018/01/11/publics-globally-want-unbiased-news-coverage-but-are-divided-on-whether-theirnews-media-deliver/ (accessed August 7, 2019).

${ }^{16}$ In the book The Old Continent and New Media, Dennis McQuail suggested the five demands of that kind: freedom, diversity, quality of information, social order and solidarity, cultural order (1994: 102-109).
} 
It is impossible to disregard that the aforementioned demands in their original form may not be fully applicable to private agents operating on the Internet and who do not even have the status of media companies. However, observed in a wider context, many similar demands are also placed before Internet intermediaries, who respond to those demands through self-regulatory mechanisms (terms of use), while some of them happen to be imposed from the above, that is, from regulatory mechanisms. For instance, freedom of expression ${ }^{17}$ is one of the fundamental freedoms, included in the ideal of the public interest and at the same time incorporated in terms of use of Facebook. "Our mission is in every respect dedicated to accepting different views. We want people to be able to talk openly about the issues that matter to them, even if some may disagree or find them objectionable. In some cases, we allow content which would otherwise go against our Community Standards - if it is newsworthy and in the public interest. We do this only after weighing the public interest value against the risk of harm and we look to international human rights standards to make these judgments" (Community Standards) ${ }^{18}$. On the other hand, numerous legal documents adopted and applicable on the territory of the European Union are exactly promoting and empowering freedom of expression on the Internet (Declaration on freedom of communication on the Internet ${ }^{19}$; EU Human Rights Guidelines on Freedom of Expression Online and Offline ${ }^{20}$ ). The diversity of information sources is another demand that, in a wider context, can be applied to the business of the aforementioned agents. For example, Facebook algorithmically determines what content will appear in users' News Feed section. The algorithm applies some general functions such as interest, topicality, proximity, etc. but also offers sponsored content based on an evaluation of user interest, which is done by monitoring activities such as liking, sharing content, contact with pages and people, etc.

So, if Facebook's algorithm "estimates" that a certain content should not be displayed to a certain user, that content may never appear in the News Feed section. Because of the ability of moderating content that is displayed to the user, Facebook could be responsible for the diversity of information sources.

Similarly, the algorithm of Google determines which results will be shown to a user in relation to the searched term and has the power to impose certain pages, while some are never shown. This attitude towards diversity and freedom, as the demand for the realization of the public interest, is certainly not identical to the traditional notion, nor should it necessarily be. The environment created by new agents on the Internet is different from the traditional communication and information system and should be approached in that manner. Napoli (2014) considers that the crucial mistakes of those shaping the communication policy are a restrictive attitude towards

\footnotetext{
${ }^{17}$ By which we mean the freedom of an individual to receive and spread information.

${ }^{18}$ Facebook Community Standards are available at: https://www.facebook.com/communitystandards/ introduction (accessed August 8, 2019).

${ }^{19}$ Available at: http://www.osce.org/fom/31507?download=true (accessed August 8, 2019).

${ }^{20}$ Available at: https://eeas.europa.eu/sites/eeas/files/eu_human_rights_guidelines_on_freedom_of_ expression_online_and_offline_en.pdf (accessed August 8, 2019).
} 
the public interest online, more precisely, a pile of recommendations and declarations that say what private companies on the Internet should do and the lack of an affirmative approach, which would encourage the demand for the fulfillment of the public interest; and secondly, the tendency to place the new environment into the old frames. Napoli believes that this topic should be approached differently: "Perhaps a more robust, expansive notion of the public interest for digital intermediaries can (and should) be built upon established media policy principles such as plurality, diversity, and localism. Or, perhaps it should emerge independently, in a way that fully reflects the particular unique characteristics of the Internet as a media platform"21.

\section{Conclusion and Discussion}

The primary goal of private companies is, unequivocally, to gain profit and achieve commercial interest, so the question of the possibility of them coordinating their business with the public interest and user interest may sound too optimistic. Namely, in order to initiate the demand for the public interest to private agents, we had to represent their role and importance in the information and communication system, as we did in the previous chapter. Undeniably, these agents perform medialike activities and the request for operating in accordance with these roles is justified. On the one hand, their power is reflected in the amount of information they are accessing: "Information is now a critical commodity, and those that control this information, whether access to or delivery of it or its content, are in key positions of power" (Laidlaw, 2008: 13).

On the other hand, their role in creating the image of the socio-political reality is more powerful, which leads us to the conclusion that the responsibility towards the public interest should be more prominent.

Napoli holds the same position and expresses concern for the "algorithmic management of the public interest" (Napoli, 2015: 756-757), while Laidlaw (2008) indicates that intermediaries are responsible for the public interest because they control our overall information experience on the Internet. In a situation where private powers are in conflict with the public interest (Laidlaw, 2008), intermediaries cannot regard their users solely as consumers, but also as citizens, to whom they owe working for their benefit, as Mansell explains: "Users play a double role insofar as they are both consumers and citizens" (2015: 3). The relation towards the public interest on the Internet or the realization of the public interest demand by private companies operating online, can be seen from the perspective of the traditional understanding of the public interest concept, but we must think of it in the context of the new information and communication environment. We consider that Internet information intermediaries should be held accountable for the content accessed through their platforms, since their influence and roles have surpassed the messenger

\footnotetext{
${ }^{21}$ Napoli,P. (2014). Digital intermediaries and the public interest standard in algorithm governance. Media
} Policy Blog. http://eprints.lse.ac.uk/80242/ (accessed August 2, 2019). 
role. The existence of editorial interventions, whether algorithmic or traditional, imposes an obligation on private companies to transparently moderate the content on their platforms and do so for the benefit of users/citizens, or in accordance with the user/public interest.

\section{References}

Allcott, H., \& Gentzkow, M. (2017). “Social media and fake news in the 2016 election”. Journal of Economic Perspectives, 31(2), pp. 211-36.

Gillespie, T. (2010). The politics of 'platforms'. New media \& society, 12(3), pp. 347-364.

Goldsmith, J., \& Wu, T. (2006). Who controls the Internet?: illusions of a borderless world. Oxford University Press.

Grimmelmann, J. (2007). "The structure of search engine law". Iowa L. Rev., 93, 1. pp. 1-63.

Jakubowicz, K. (2009). "A new notion of media?". In 1st Council of Europe Conference of Ministers Responsible for Media and New Communication Services, Council of Europe, Strasbourg Cedex: Council of Europe.

Laidlaw, E. B. (2008). Private power, public interest: An examination of search engine accountability. International Journal of Law and Information Technology, 17(1), pp. 113-145.

Lotan, G., Graeff, E., Ananny, M., Gaffney, D., Pearce, I., \& Boyd, D. (2011). The Revolutions Were Tweeted: Information Flows during the 2011 Tunisian and Egyptian Revolutions. International Journal of Communication, 5, 1375-1405.

Mansell, R. (2015). The public's interest in intermediaries. info: The Journal of Policy, Regulation and Strategy for Telecommunications, Information and Media, 17(6), pp. 8-18.

Mek Kvejl, D. (1994). Stari kontinent-novi mediji. Beograd: Nova.

Musiani, F. (2013). "Dangerous Liaisons? Governments, companies and Internet governance". Internet Policy Review, 2(1). URL: https://policyreview.info/articles/ analysis/dangerous-liaisons-governments-companies-and-internet-governance

Napoli, P. M. (2015). "Social media and the public interest: Governance of news platforms in the realm of individual and algorithmic gatekeepers". Telecommunications Policy, 39(9), pp. 751-760.

Palfrey, J. (2010). Four phases of internet regulation. Social Research, pp. 981-996.

Perset, K. (2010). "The Economic and Social Role of Internet Intermediaries". OECD Digital Economy Papers, No. 171, OECD Publishing. URL: http://dx.doi. org/10.1787/5kmh79zzs8vb-en.

Radok, E. (2015). Mladi i mediji. Beograd: Clio.

Rainie, H., Anderson, J. Q., \& Albright, J. (2017). The future of free speech, trolls, anonymity and fake news online. Washington, DC: Pew Research Center. 


\section{Website}

A Declaration of the Independence of Cyberspace, by John Perry Barlow, 1996. Davos, https://www.eff.org/cyberspace-independence (accessed August 3, 2019).

Declaration on freedom of communication on the Internet: http://www.osce.org/ fom/31507?download=true (accessed August 8, 2019).

EU Human Rights Guidelines on Freedom of Expression Online and Offline: https:// eeas.europa.eu/sites/eeas/files/eu_human_rights_guidelines_on_freedom_of_ expression_online_and_offline_en.pdf (accessed August 8, 2019).

Mitchell, A., Simmons, K., Matsa, K. E., \& Silver, L. (2018). Publics globally want unbiased news coverage, but are divided on whether their news media deliver. Pew Research Center's Global Attitudes Project. http://www.pewglobal.org/2018/01/11/detailedtables-global-media-habits/ (accessed August 5, 2019).

Napoli, P. (2014). "Digital intermediaries and the public interest standard in algorithm governance”. LSE Media Policy Project Blog. http://blogs.lse.ac.uk/ mediapolicyproject/2014/11/07/digital-intermediaries-and-the-public-intereststandard-in-algorithm-governance/ (accessed August 4, 2019).

Standardi zajednice na Fejsbuku, u delu Glas, dostupno na: https://www.facebook.com/ communitystandards/ (accessed August 5, 2019).

Shearer, E., Gottfired, J. (May 16, 2016). News Use Across Social Media Platforms 2016. Pew Research Centre. URL: https://www.journalism.org/2016/05/26/news-useacross-social-media-platforms-2016/ (accessed August 6, 2019).

Thielman., S. (12 May 2017). "Facebook news selection is in hands of editors not algorithms, documents show". The Guardian.. https://www.theguardian.com/technology/2016/ may/12/facebook-trending-news-leaked-documents-editor-guidelines (accessed August 5, 2019).

Kovach, S. (October 14, 2017). Facebook and the rest of Big Tech are now Big Media, and it's time we start treating them that way. Business Insider. URL: https://www. businessinsider.com/facebook-and-google-are-now-media-companies-2017-10 (accessed August 5, 2019).

Serwer, A., Zahn, M. (March 5, 2019). Why Facebook, Google, and Twitter don't want to be media companies. Yahoo Finance. Dostupno na: https://finance.yahoo.com/news/ google-facebook-twitter-media-165635516.html (accessed August 5, 2019).

\section{TRAŽEĆI JAVNI INTERES NA INTERNETU}

Apstrakt. Novim informaciono-komunikacionim okruženjem na internetu gospodare privatni akteri - internet intermedijatori. Premda bismo već iz njihovog naziva mogli da izvedemo zaključak da su oni posrednici u komunikaciji na internetu, te da su njihove platforme vrednosno neutralne i po prirodi tehničke - vođene algoritmima, ne možemo a da se ne osvrnemo na njihovu ulogu u diseminaciji informacija i na uticaj na korisnike, koji prevazilazi samo tehničko posredovanje. Cilj ovog rada jeste da ukaže na to da društvene mreže i pretraživači, kao internet intermedijatori, nisu samo tehno- 
giganti, već da u pojedinim aspektima obavljaju funkcije nalik medijskim, te da bi im se u skladu sa tom ulogom trebalo i pristupiti. Iako privatne kompanije, ovi novi akteri trebalo bi da, pored komercijalnih, ispune i zahteve korisnika, koji nisu samo puki potrošači njihovih usluga, već su i građani. Iz pozicije građana, korisnici od njih mogu da zahtevaju ispunjenje javnog interesa, koji ne mora, niti bi nužno trebalo, da je istovetan tradicionalnom shvatanju tog koncepta, već uslovljen kontekstom i okruženjem u kojem se zahtevi za njim uрuс́uju.

Ključne reči: internet, intermedijatori, javni interes, pretraživači, društvene mreže 